\title{
Sustainability implementation challenges in food supply chains: A case of UK artisan cheese producers
}

\begin{abstract}
Food supply chains are receiving increased attention due to the rapid depletion of natural resources, increasing quality standards and rising food safety and security concerns regarding contamination and fraud. Implementing sustainability practices in food supply chains is believed to overcome emerging challenges at both regional and global levels. However, limited studies address sustainability implementation concerns particularly in cold food supply chains. This study aims to contribute to this evident research gap by addressing the major factors hindering sustainability implementation in these networks by considering a case of UK artisan supply chain. Survey data from the UK artisan cheese producers are utilized to identify and prioritise barriers for implementing sustainability following a fuzzy analytic hierarchy process and sensitivity analysis. The analysis identified several key barriers including initial investment cost, firm size and unawareness of government regulations. The internal barriers significantly dominate implementation of sustainability practices in comparison to the external barriers. Lack of consensus regarding the concept of sustainability by different stakeholders was observed to be an issue negatively affecting the level of integration in SMEs. The findings will be highly useful for food and dairy SME's to gain competitive advantage through the successful implementation of sustainability practices.
\end{abstract}

\section{Keywords}

Sustainability, Food supply chains, UK dairy sector, Sustainability implementation, SMEs, Cold food chains 


\section{Introduction}

Steadily growing competition, outsourcing and short product lifecycles have increased the level of disruption in global supply chains (Ortas et al. 2014). At the same time, there has been a growing demand towards embracing sustainability practices through lean, green and socially responsible corporate policies (Giunipero et al. 2012; Choudhary et al. 2019). Today's customers are concerned regarding the product origin, while governments are strengthening the environmental regulations on firms (Kanji and Chopra 2010; Bourlakis et al. 2014a). Compliance with regulations and high-quality standards demanded by the customers have brought a paradigm shift in the development and integration of sustainability policies. Especially, food supply chains comprise of a dynamic environment characterised by the rising consumer expectations for food safety, quality and sustainable production methods (Ghadge et al. 2017). These supply chains have to align their (operations and marketing) functions with eco-friendly principles to achieve sustainability expectations.

Dairy supply chains constitute an economically important part of the agricultural sector that extends beyond national boundaries. The global demand for dairy products is estimated to be around 15 million tonnes per annum (Fonterra 2014) and is increasing exponentially. However, it is also among the most vulnerable sectors to the climate change threat (Dairy Roadmap 2015). Dairy supply chains are highly energy-intensive (Glover et al. 2014), due to the perishable nature of the milk-based products requiring refrigeration (Ghadge et al. 2017). The dairy supply chain is an uninterrupted series of temperature controlled (cold) production, storage and distribution activities (Kuo and Chen 2010). The dairy industry comprises limited producers and faces particular challenges in terms of bringing sustainable practices to their operations (Svensson and Wagner 2012). Particularly, barriers for implementing sustainable practices in small and medium enterprises (SMEs) are different to large enterprises (Govindan et al. 2014; Shibin et al. 2018). In recent years, dairy supply chain partners have mobilised a considerable amount of funds to implement sustainability in their operations (Hamprecht et al. 2005). However, only a few articles study sustainability implementation challenges in fresh food or dairy supply chains (e.g. Svensson and Wagner 2012; Glover et al. 2014; Bourlakis et al. 2014b; Ghadge et al. 2017). Increased importance of food supply chains (FSC) due to climate change and resource scarcity, and investigation of the hindering factors for sustainability implementation has become crucial for global supply chains. Furthermore, identification of such influential factors is necessary for gaining competitive advantage (Grimm 
et al. 2014; Beske et al. 2014; Xia et al. 2015; Longoni and Cagliano 2015; Wang et al. 2016). By using UK artisan cheese producers as a case study, the research attempts to contribute to bringing clarity in terms of inherent challenges for implementing sustainability practices in food SCs. Furthermore, these insights are expected to support in gaining competitive advantage through successful implementation of sustainability practices. In order to achieve these, the study addresses the focal research question of: What are the key barriers impacting sustainability implementation in the artisan cheese supply chain?

The literature review explores generic challenges to implementing sustainability in supply chains. A survey questionnaire developed using information from the literature review facilitated responses from UK artisan cheese producers. The Fuzzy Analytical Hierarchy Process (Fuzzy-AHP) method is used to analyse and assess the level of importance within the identified barriers. The research aims to identify key factors negatively influencing sustainability implementation in the UK artisan cheese supply chain.

The rest of the paper is presented as provided below. An extensive literature review of the factors influencing the sustainable practices in supply chain management is discussed in section 2. The research methodology section discusses the data collection and analysis approach in section 3. Data analysis, in section 4, looks at the priority of each barrier and subbarrier. Barrier comparison is conducted following sensitivity analysis in section 5. Section 6 concludes with a discussion on research implications, limitations and future research directions.

\section{Literature Review}

\subsection{Sustainable Supply Chain Management}

Sustainability is referred to as "development that meets the needs of the present without compromising the ability of future generations to meet their own needs" (World Commission on Environment and Development 1987). Elkington (1998) defines sustainability as the principle of ensuring that today's actions do not limit the range of economic, social and environmental options open to future generations and calls this principle the 'triple bottom line approach' (Carter and Rogers 2008). Growing environmental and social problems have raised the awareness of sustainability among industries as well as regulatory bodies (Govindan et al. 2014). Governmental pressures could trigger implementation of environmental management across the business (Tian et al. 2014). Another trigger comes from stakeholders, since they strongly influence the corporate strategies of the firm (Vachon and Klassen 2008). Sustainable 
Supply Chain Management (SSCM) emerges as an organisational approach to instil environmental, economic and social awareness in the traditional SCM (Sarkis et al. 2011; Cole and Aitken, 2019). The scope of SSCM varies from sustainable procurement to the environmentally and socially conscious customer (Zhu and Sarkis 2004). Previous studies have overlooked the possible expansion of competitive advantages following the SSCM as a base (Markley and Davis 2007). Organizations need to increase their attention on social implications including consumer satisfaction, employee satisfaction, unemployment, corporate social responsibility and government rating of environmental performance along with economic implications (Markley and Davis 2007). In recent times, dairy supply chains have been receiving growing attention from researchers and practitioners due to the escalating demand of dairy products and associated recent food frauds (Wognum et al. 2011; Siddh et al. 2017; Luo et al. 2018).

Two main characteristics through which organizations can obtain competitive benefits from sustainability practices involve cost leadership and product differentiation (Ojo et al. 2015). Organisations should focus on crucial knowledge and information about the quickchanging customer demands and nature of competition (Guo 2007). Natural resources are depleting every day; thus, it is essential for all organisations to develop new competencies, resources and measures (Rodriguez et al. 2002) in order to remain competitive. Implementation of sustainability practices such as pollution control, green purchasing, green processes, recycling and reverse logistics helps to improve the rating of firms for environmental performance (Mogale et al. 2019a). Such initiatives also meet customer expectations. Thus, in today's highly volatile and competitive market, it is vital for organisations to focus on the improvement of sustainability practices for competitive advantage.

The following sections provide information on the internal and external sustainability implementation barriers within SCM. We adopt the internal and external classification provided by Walker et al. (2008) for green SCM practices.

\subsection{Internal factors}

Internal factors emerge from within the organisation (Walker et al. 2008). They are primarily organised into management and operations barriers based on the insights generated from the literature review. Following approach followed by Ghadge et al. (2017), the management barrier was further sub-categorised into misinterpretation of sustainability, stakeholder inertia and focus on short-term strategic goals. Similarly, the operations barrier was categorised into 
initial investment cost, return management and firm size and their resource capability. Each of these internal sub-categories was the result of the findings made through the literature review. Among the aforementioned barriers, the initial investment cost, focus on short term strategic goals and return management are economic barriers, whereas misinterpretation of sustainability comes under the category of environmental barriers. The social barriers include stakeholder inertia, firm size and resource capability.

\section{Management}

Misinterpretation of the sustainable development by organisations has been identified as a common barrier to the implementation of sustainability (Giunipero et al. 2012, Paillé et al. 2013, Johnson 2015), which can be attributed to the lack of consensus regarding sustainability. This negative situation occurs more in the food industry (especially fresh food) due to the inherent complex challenges in the sector; e.g., natural resource usage; sustainable land management, and, safe, healthy and nutritious food for the consumers (Yakovleva 2007). As a consequence of this difficulty, top-management struggles to prioritise activities inter-related to the environmental, economic and social dimension. The lack of direction from the government regarding regulation/policy on sustainability can also significantly delay implementation. The inappropriately defined reward norms and lack of measurement of progress significantly hinder the implementation of sustainability (Giunipero et al. 2012). Along with the difficulty of comprehending the nature of sustainability, stakeholder inertia is found to be another challenge for organisations to overcome (Govindan et al. 2014). Adoption of theoretical concepts in sustainability is necessary for increasing the level of industry inertia (Stål 2015). This management challenge is associated with the stakeholder's lack of commitment to implementing sustainable practices. Some organisations are not ready to take up a sustainable management system due to ignorance and lack of preparedness (Mudgal et al. 2010). More than being a knowledge barrier, lack of management initiative to know more about sustainability is due to their disbelief in the benefits they can achieve from sustainability implementation. Lack of inertia to drive the senior management's focus is influenced by high uncertainty involved in such investment along with difficulty in realigning current processes to meet sustainability objectives (Abbasi and Nilsson 2012). Top management's commitment is also equally vital considering the radical changes demanded by sustainability implementation (Roehrich et al. 2014). The process becomes even more challenging given the priority dilemma, which emerges due to the interrelation of long-term oriented environmental and social aspects of sustainability with traditional short-term objectives (Longoni and Cagliano 2015). Multiple 
previous studies indicated that the financial performance (return on investment and return on sales) of various strategic configuration models is almost equally supported by equifinality theory (Luz and Diaz-Garrido, 2008, Zhao et al., 2006, Doty et al., 1993). The improvement in a firm's image and enhancement of loyalty of stakeholders are the two key long-term benefits of sustainability implementation (Burgos-Jimenez et al., 2013, McWilliams and Siegel, 2011, Goodman, 2000). Further, Longoni and Cagliano (2015) argue that additional operations can achieve better long- and short-term performance with environmental and social sustainability along with complementing capability-oriented operations strategies. Misalignment of the strategic goals concerning sustainable development is another challenge faced by recent supply chain networks and may lead to conflicting operations and loss of focus of employees (Giunipero et al. 2012). The lack of awareness about various drivers and issues among managers pertaining to their firms and no common definition for sustainability are a few of the reasons behind this misalignment (Giunipero et al. 2012).

\section{Operations}

Initial investment cost is represented as the most important barrier to sustainability development (Walker et al. 2008; Bourlakis et al. 2014a). The initial cost of implementation of sustainability practices is high and, hence, makes it difficult to realise the financial returns (Mathiyazhagan et al. 2013). Investment cost is a greater obstacle for SMEs due to their limited resource availability, which makes them vulnerable (Walker et al. 2008; Bourlakis et al. 2014a; Ghadge et al 2017). Therefore, possession of adequate funds, as well as the employment of qualified human capital are imperative to driving sustainability activities (Schrettle et al. 2014). These employment activities contribute towards social sustainability by reducing the unemployment rate of the specific region. Hence, firm size and resource capability are the major operational barriers which describe the social aspect of sustainability. Supply chains are ready to implement sustainability only if their profit quotient is not affected (Govindan et al. 2014). The 'green' initiative can be expensive to organisations on short-term basis because they have to invest in more energy efficient technologies and equipment. Environmentally friendly resources and manufacturing processes increase the cost of operations (Koplin et al., 2007) Therefore, if there is no return on investment, firms refrain from spending on sustainable practices.

An additional factor identified towards sustainable development is firm size. Despite the fact that large firms reap the benefit of having a greater influence across the supply chain 
network, smaller firms tend to exhibit excellent sustainability performance on account of the flexibility their size provides (Bourlakis et al. 2014a; Bourlakis et al. 2014b). Small manufacturers fail to identify the benefits of sustainability improvement such as cost reduction and profit enhancement (Epstein and Roy 2000). The European Union has defined SMEs as firms consisting of a maximum of 250 employees with an annual turnover of up to 50 million euros (European Commission, 2015). These enterprises represent 99\% of all businesses in the European Union (Johnson and Turner 2000).

Effective reverse logistics is also recognised as a significant factor towards the sustainability of an organization's operations (Abbasi and Nilsson 2012; Mollenkopf et al. 2011). Reverse logistics avoids wastage by encouraging reuse and recycling of products. However, product returns management been overlooked due to the organization's sole emphasis on minimisation of operational costs (Mollenkopf et al. 2011; Ghadge et al. 2017). Modern environmental legislation requires companies to adjust their focus by adopting sustainable programs such as collection strategies, repair services, remanufacturing and disposition of recovered products and packaging (Abbasi and Nilsson 2012). Table 1 depicts the important key barriers identified from the extant literature.

Table 1 Identified internal barriers for sustainability from literature

\begin{tabular}{ll}
\hline \multicolumn{1}{c}{ Internal barriers } & \multicolumn{1}{c}{ References } \\
\hline $\begin{array}{l}\text { Management (MG) } \\
\text { 1. Misinterpretation of sustainability } \\
\text { (MG1) }\end{array}$ & $\begin{array}{l}\text { White et al., (2012), Giunipero et al., (2012), } \\
\text { Johnson (2015) and Paillé et al. (2013) } \\
\text { 2. Stakeholder inertia (MG2) }\end{array}$ \\
$\begin{array}{l}\text { Abbasi and Nilsson (2012), Roehrich et al. (2014), } \\
\text { Govindan et al. (2014), Wu and Pagell (2011) } \\
\text { G. Misalignment of strategic goals } \\
\text { (MG3) }\end{array}$ & $\begin{array}{l}\text { (2015), Wu and Pagell (2011) } \\
\text { Operations (O) }\end{array}$ \\
$\begin{array}{l}\text { 1. Initial cost of investment (O1) } \\
\text { Bourlakis et al., (2014a), Gallear, and Fotopoulos } \\
\text { 2. Returns Management (O2) }\end{array}$ & $\begin{array}{l}\text { (2014), Abbasi and Nilsson (2012), Ghadge et al. } \\
\text { Shaharudin et al. (2015), Sharma et al. (2011), } \\
\text { Alvarez-Gil et al. (2007), Mollenkopf et al. (2011) } \\
\text { Mathiyazhagan et al. (2013), Bourlakis et al., } \\
\text { (2014b), Ageron et al. (2012), Walker and Jones }\end{array}$ \\
\hline
\end{tabular}




\subsection{External factors}

External barriers are influenced by outside activities associated with the organisation and are structured into suppliers, regulations and market categories (Ghadge et al. 2017). The supplier's barrier category includes an unwillingness to exchange information, their firm size and perception regarding sustainability. The regulation category involves environmental regulations and insufficient support from the relevant bodies such as governments and environmental agencies. The market barrier category comprises of poor market structure, consumers' eco-literacy and product price (Ghadge et al. 2017). The supplier barriers, consisting of collaboration with vendors and unwillingness to exchange information, are social barriers. The environmental barriers involve regulation and support from government and environmental agencies. The market related barriers hinder the economic improvement of organisations. The following section provides detailed discussion associated with each external barrier.

\section{Suppliers}

Suppliers are an integral part of the global supply chain network. Collaboration between focal firm and supply chain partners has been highlighted in the literature as a critical factor towards the integration of sustainability practices (Ageron et al. 2012; Grimm et al. 2014). The degree of integration with suppliers on sustainability performance has a direct impact on the focal firm's performance (van der Vaart and van Donk 2008; Gualandris and Kalchschmidt 2014). The importance of the supplier's commitment to supporting environmental initiatives is justified by their position in their supply chain network. The various food scandals across the globe, including the China's melamine milk (2008) and European horse meat (2013) raise the question of food quality. Thus, consumers are demanding more information on farming, processing, marketing, distribution and transportation activities (Ahumada and Villalobos, 2009). Food fraud incidents and the negative environmental impact of food influences the brand image and reputation of a company. Cooperation among all the actors involved in the supply chain is necessary to enhance sustainability (Govindan et al. 2014). Sustainability collaboration with supply chain partners is a joint information-sharing measure to reduce environmental impact (Grekova et al. 2016). The lack of trust is held responsible for causing collaboration inefficiencies between suppliers and the focal firm (Mathiyazhagan et al. 2013, Ghadge et al. 2017). Sharing the same sustainability principles is vital to the sustainable performance of the network (Mathiyazhagan et al. 2013). Nevertheless, firms are not always 
capable of successfully enforcing their assessment and development agendas on their supply chain partners (Ciliberti et al. 2008). Concerning sustainable performance, the financial capabilities and firm size of suppliers are of substantial importance (Ghadge et al. 2017). Suppliers with strong financial resources and a bigger firm size are most inclined towards engaging in social sustainable practices over others (Bourlakis et al. 2014a; Cole and Aitken, 2019). In contrast, small suppliers face difficulty while investing in additional resources for sustainability improvement.

\section{Regulations}

Environmental legislation is another significant factor in the implementation of sustainable practices (Uhlaner et al. 2012; Giunipero et al. 2012). Some of the past research (e.g., Gadenne et al. 2009) indicates that legislation does not always result in environmental awareness. However, the lack of international environmental standards increases implementation complexity in global supply chain networks (Giunipero et al. 2012). The regulatory authorities' inadequate support and guidance also constitute an impediment to environmental sustainability (Govindan et al. 2014). Support in terms of training, consultancy and monitoring sustainable processes, as well as financial assistance, usually entails government regulations (Ageron et al. 2012; Bourlakis et al. 2014a).

Compliance with legislation is core to operations, as failure to conform may result in hefty fines and sometimes revocation of the licence. In several developed countries, regulations are passed to hold SC partners responsible for not adhering to sustainability regulations (Mitra and Datta 2014; Shaharudin et al. 2015). Firms must comply with the environmental legislation or face legal action (including exorbitant penalties) (Sarkis et al. 2011). However, there is inconsistency concerning the impact of regulation on the differently sized firms. It is suggested that, while larger firms have the financial capability to adhere to environmental legislation and standards, smaller firms' resource scarcity frequently limits their capacity to take protective measures and forces them to suspend operations (Darnall et al. 2010). SMEs' limited financial capacity and inadequate support from the authorities hinder the conformance to sustainability regulations.

\section{Market}

The food industry is characterised by a dynamic competitive environment where demand and supply are highly volatile (Yakovleva 2007). Market competition and fragmentation pose a challenge through the limitation of available suppliers (Walker et al. 2008). Lack of customer's 
sustainability awareness further discouraging firms from incorporating sustainable exercises (Giunipero et al. 2012; Govindan et al. 2014; Ghadge et al. 2017). Apart from other internal and external factors towards the implementation of sustainable initiatives, product cost is regarded as a significant behaviour modulator for purchasing of green commodities (Ramirez et al. 2014). Especially in times of recession, customers tend to neglect the potential benefits of purchasing sustainable food, as they perceive them to be an additional cost burden (Giunipero et al. 2012). During a financial crisis, markets (firms and customers) prioritise the economic aspect over the social and environmental dimensions of sustainability (Reuter et al. 2012).

Table 2 Identified external barriers for sustainability from literature

\begin{tabular}{ll}
\hline \multicolumn{1}{c}{ External barriers } & \multicolumn{1}{c}{ References } \\
\hline $\begin{array}{l}\text { Suppliers (S) } \\
\text { 1. Unwillingness to exchange } \\
\text { information (S1) }\end{array}$ & $\begin{array}{l}\text { Govindan et al. (2014), Grimm et al. (2016), Kache and } \\
\text { Seuring (2014), Ageron et al. (2012), }\end{array}$ \\
$\begin{array}{l}\text { 2. Suppliers' firm size (S2) } \\
\text { Bourlakis et al., (2014a), Giunipero et al. (2012), } \\
\text { Schrettle et al. (2014), Walker et al. (2008), Cole and }\end{array}$ & $\begin{array}{l}\text { Aitken (2019) } \\
\text { Ageron et al. (2012), Sajjad et al. (2015), Schäufele and }\end{array}$ \\
$\begin{array}{l}\text { 3. Perception regarding } \\
\text { sustainability (S3) }\end{array}$ & $\begin{array}{l}\text { Hamm (2017) } \\
\text { Regulation (R) }\end{array}$ \\
$\begin{array}{l}\text { 1. Environmental regulations (R1) } \\
\text { 2. Insufficient guidance (R2) }\end{array}$ & $\begin{array}{l}\text { Giunipero et al. (2012), Walker et al. (2008), } \\
\text { Bourlakis et al., (2014a), Ageron et al. (2012), } \\
\text { Govindan et al. (2014) }\end{array}$ \\
$\begin{array}{l}\text { 3. Lack of regulatory knowledge } \\
\text { (R3) }\end{array}$ & $\begin{array}{l}\text { León-Bravo et al. (2020) } \\
\text { Market (MAR) }\end{array}$ \\
$\begin{array}{l}\text { 1. Market structure (MAR1) } \\
\text { 2. Consumer's eco-literacy } \\
\text { (MAR2) }\end{array}$ & $\begin{array}{l}\text { Walker et al. (2008), Schrettle et al. (2014), Mogale et } \\
\text { al. (2019a) }\end{array}$ \\
Gualandris and Kalchschmidt (2014), Mathiyazhagan et \\
al. (2013), Govindan et al. (2014), Reuter et al. (2012), \\
Ghadge et al. (2017) \\
Ramirez et al. (2014), Roehrich et al. (2014), Reuter et \\
al. (2012), Mogale et al. (2019b)
\end{tabular}

The market involves consumer organisations, media, politics and local communities (Schrettle et al. 2014). The agents mentioned above act according to certain societal values and exert pressure on internal stakeholders to implement environmental practices (Uhlaner et al. 2012). The increased environmental awareness amplifies this pressure due to climate change 
and depletion of natural resources (Ateş et al. 2012; Ghadge et al., 2019). Product price is a key factor which mostly influences the buying decisions of customers (Ramirez et al. 2014). The adoption of sustainable products and services increases the financial pressure on end consumers (Walley \& Whitehead, 1994). Some manufactures are not interested in implementing sustainability practices due to costly raw materials and semi-finished products. All costs incurred for sustainability efforts have to borne by the customers and most consumers show an unwillingness to pay premium prices for sustainable products (Ramirez et al. 2014). Therefore, organisations have to make sustainable products at affordable prices which can help to improve the social benefits. The trade-off between the three dimensions of sustainability can be observed from the aforementioned argument. Consequently, sustainable products can be produced to improve public health, but this escalates product prices. Thus, firms have to evaluate the trade-off between these three dimensions to achieve sustainability in fresh food supply chains. Another barrier towards sustainable development is the quality of the logistics infrastructure. The crucial external barriers for sustainability implementation are reported in Table 2 .

\subsection{Artisan Cheese Industry}

There has been a significant increase in the number of artisanal dairy products over the past decade (Bouma et al. 2014). Artisan dairy producers transform the raw milk into fresh cheese through the traditional craftsmanship of skilled cheesemakers. The supply and demand of milk dictates the cost of production. Several operational challenges such as lack of equipment and training to produce the best quality product are faced by producers (Holmann 2001), along with the limited shelf life of artisan cheese. Finding new customers and a relevant market for distribution of the product is another critical challenge for this SME-based supply chain network. The typical structure of the supply chain network and layout of the artisan cheese factory is provided in Figure 1. Contamination of the cheese leads to food safety issues, which is a common occurrence in this industry due to the use of unpasteurised milk for this specialist cheese-making process (Waldman and Ker 2015). Figure 1 shows the different stages and layouts involved in producing artisan cheese. Food supply chain network at the top shows the associated link with the production node.

The artisan cheese industry faces several challenges; however, the most critical is associated with contamination. Listeria and E-coli outbreaks in 2010 and 2016, respectively, were found to be associated with artisan cheese (NY Times 2010; Sustainable food trust 2017). 
Food safety-related recall practices are not well established in this industry due to the relatively small scale of the sector. Moreover, the process of making artisan cheese is not transparent (non-standardised) and consistent across the industry due to the traditional nature of cheese making (Le et al. 2014). Short shelf life creates additional challenges for storage and transportation to the market. The outcome of these challenges leads to food waste if food is recalled due to contamination or loses shelf life due to improper handling and storage. Another challenge faced by artisan cheese producers is forecasting demand as the retail channels may be limited on account of product type.

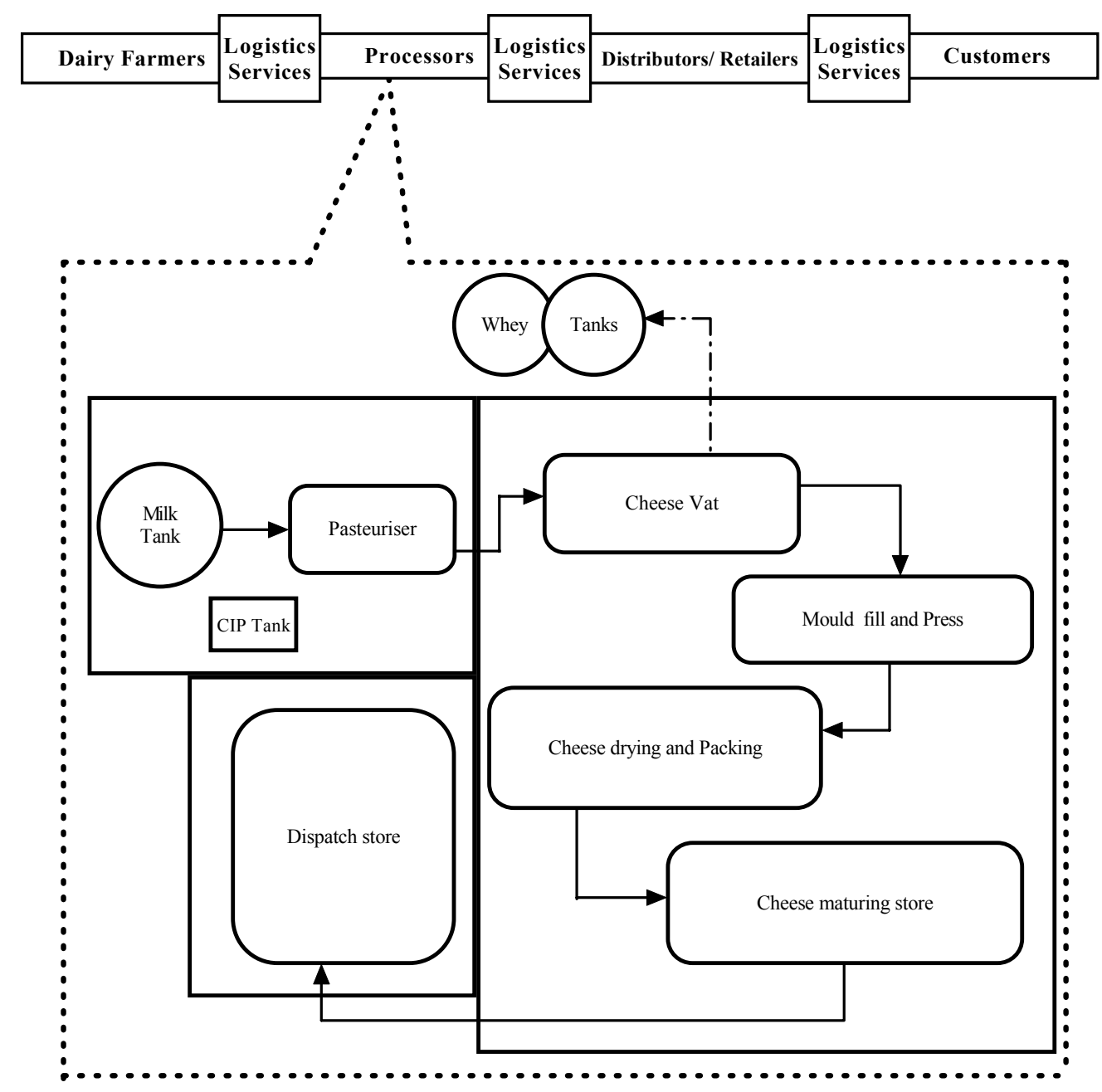

Figure 1. Typical food supply chain and Artisan cheese factory structure

Considering the triple bottom line concept of sustainability, it is imperative to study the sustainability challenges of artisan cheese producers using economic, environmental and social challenges. The academic research on this topic and sector is limited but some academic papers have considered the challenges of operating costs (Bouma et al., 2014), food safety (Waldman 
and Kerr 2015), perceptions of food safety and quality (Le et al. 2014), and pricing (Durham et al. 2015) for artisan cheese producers which, in turn, have an influence on various sustainability parameters. This research will endeavour to understand the barriers for implementing sustainability practices within artisan cheese supply chains.

\section{Research Methodology}

The study employed a two-stage approach to data collection and analysis. The first stage investigated the relevant literature within SCM to identify the barriers to sustainability implementation. Different types of SCs such as automotive, retail, construction, food, etc., were considered to capture a comprehensive picture of the challenges. All the identified factors were later filtered based on the relevance to the FSC for developing the questionnaire survey. The internal and external barriers for the implementation of sustainability practices in food supply chains were identified through the literature review and discussions with UK artisan producers and academic researchers studying in the relevant fields. Four researchers and two practitioners working in the food/dairy supply chain were asked to identify three key factors from internal and external barriers. The defined internal and external barrier categories and sub-categories are shown in Table 1. In the second stage, a structured questionnaire was developed and deployed to UK artisan cheese producers to collect the data. The final dataset consisted of 55 respondents who evaluated the identified main sustainability barriers and their sub-categories by using a nine-point fuzzy scale. The fuzzy AHP method was employed to identify, weigh, and prioritise the key barriers from the survey data. Finally, a sensitivity analysis was performed. The AHP is a popular and extensively used decision support tool for solving the complex problems in business industries (Govindan et al. 2014).

The questionnaire was first piloted on cheese producers attending the UK's largest artisan cheese fair, 2015 held in Leicestershire, UK. The pilot survey attracted a good response (516) with further suggestions for improvement in the questionnaire. The improved survey was sent to 472 artisan cheese producers in the UK. The contact details for the respondents were obtained from the artisan cheese fair, UK dairy business database, and by visiting local cheese managers in and around Leicestershire, Yorkshire and Lothian in the UK. The survey data were collected in-person and online using semi-structured questionnaire between April to December 2015; 55 responses were received (11.6\% response rate). An overall response rate of more than $10 \%$ is evaluated as sufficient for the positive assessment of the survey in the production 
and operations management research domain (Malhotra and Grover 1998). Hence, the sample size and response rate are believed to be sufficient for researching driver and barrier identification. The sample captures the data across the country and, hence, is a good representative of the artisan cheese supply chain network in the UK.

The online survey platform Survey Monkey ${ }^{\mathrm{TM}}$ was used to deploy the online questionnaire. The first part of the questionnaire was aimed at receiving generic information of the firm and its position in the supply chain network; the second part was focused on the level of importance and relationship of each barrier to their firm. Fuzzy-AHP is a robust approach for priority ranking of different variables (Chang 1996; Singh et al., 2017; Sirisawat and Kiatcharoenpol 2018). The process has an inherent ability to handle intangibles and measure consistency in the decision maker's judgement (Javanbarg et al. 2012). The second part of questionnaire survey was structured to meet the requirements for fuzzy-AHP analysis, as the approach facilitates the conversion of linguistic information into tangible information. The applied fuzzy-AHP process used a nine-point fuzzy scale in Sirisawat and Kiatcharoenpol (2018) is provided in Appendix I. The structured questionnaire expressed the level of preference from "extreme importance" to "equal importance" with each preference expressed in a numeral form. A brief overview of the fuzzy-AHP process is provided in the following section.

The specification between micro, small and medium firm was based on the European Commission's (2015) definition of SMEs. It is evident that the vast majority of firms were micro $(76 \%)$. On the other hand, small and medium firms accounted for $20 \%$ and $4 \%$ respectively. Low response from medium-size enterprises is not associated with low interest in the study but, rather, a general lack of some medium enterprises in such a highly traditional small business (Dandy et al. 2015). The sourcing of the raw milk is an important process within the artisan cheese process as it is one of the key ingredients used. From the responses it is evident that almost half of the respondents sourced milk exclusively from external producers, whereas 17 respondents were producing it in-house. The remaining 13 firms were using both external and internal sources for raw milk.

\subsection{Fuzzy Analytical Hierarchy Process}

AHP is a multi-criteria decision-making approach that examines a problem with a multihierarchical structure and uses pairwise comparisons to obtain the data set (Singh et al., 2017). 
Chang (1996) proposes the use of triangular fuzzy numbers for pairwise comparison, and the use of the extent analysis method in fuzzy AHP. A fuzzy number $M$ on $R$ is defined as a triangular fuzzy number if its membership function $\mu_{M}(x): R \rightarrow[0,1]$ is equal to Equation 1 (Chang, 1996).

$$
\mu_{M}(x)=\left\{\begin{array}{cc}
\frac{x}{m-l}-\frac{l}{m-l}, & x \in[l, m] \\
\frac{x}{m-u}-\frac{u}{m-u}, & x \in[m, u] \\
0, & \text { otherwise }
\end{array}\right\}
$$

In equation $1, l \leq m \leq u$, where $1, \mathrm{~m}$, and $\mathrm{u}$ correspond to the lower, upper, and modal values of the support of $\mathrm{M}$, respectively. The triangular fuzzy number $M$ can be represented by $M=$ $(l, m, u)$.

The steps of fuzzy AHP process are explained in the following.

Step 1: The fuzzy evaluation matrix_A $A=\left(a_{i j}\right)_{n x m}$ is constructed via pairwise comparison by using triangular fuzzy numbers. $a_{i j}$ is a fuzzy number that represents the judgement on the importance of element $i$ over element $j$ and denoted by $a_{i j}=\left(l_{i j}, m_{i j}, u_{i j}\right)$.

$\underline{\text { Step 2: }}$ Let $M_{g_{i}}^{1}, M_{g_{i}}^{2}, \ldots, M_{g_{i}}^{m}$ be values of extent analysis of $\mathrm{i}^{\text {th }}$ criterion. Then the value of fuzzy synthetic extent with respect to the $i^{\text {th }}$ criterion can be calculated by using equation 2 (Chang 1996; Sirisawat and Kiatcharoenpol 2018).

$$
\begin{gathered}
S_{i}=\sum_{j=1}^{m} M_{g_{i}}^{j} \odot\left[\sum_{i=1}^{n} \sum_{j=1}^{m} M_{g_{i}}^{j}\right]^{-1} \\
=\left(\sum_{j=1}^{m} l_{i j}, \sum_{j=1}^{m} m_{i j}, \sum_{j=1}^{m} u_{i j}\right) \odot\left(\frac{1}{\sum_{i=1}^{n} \sum_{j=1}^{m} u_{i j}}, \frac{1}{\sum_{i=1}^{n} \sum_{j=1}^{m} m_{i j}}, \frac{1}{\sum_{i=1}^{n} \sum_{j=1}^{m} l_{i j}}\right)
\end{gathered}
$$

Step 3: Estimates of the weights are obtained by using the comparison principle of Chang (1996) for fuzzy numbers. The degree of possibility of $M_{1} \geq M_{2}$ is defined by $V\left(M_{1} \geq M_{2}\right)$. Equation 2 shows the calculation of $V\left(M_{1} \geq M_{2}\right)$ and $V\left(M_{2} \geq M_{1}\right)$ that are needed to compare $M_{1}$ and $M_{2}$. All $\mathrm{S}_{\mathrm{i}}$ values are compared by using equation 3.

$$
\left(\mathrm{M}_{2} \geq \mathrm{M}_{1}\right)=\operatorname{hgt}\left(M_{2} \cap M_{1}\right)= \begin{cases}1 & \text { if } m_{2} \geq m_{1} \\ 0 & \text { if } l_{1} \geq u_{2} \\ \frac{l_{1}-u_{2}}{\left(m_{2}-u_{2}\right)-\left(m_{1}-l_{1}\right)} & \text { otherwise }\end{cases}
$$

The degree of possibility for a convex fuzzy number to be greater than k convex fuzzy numbers $M_{i}(i=1,2, \ldots, k)$ can be defined as in the following:

$$
V\left(M \geq M_{1}, M_{2}, \ldots, M_{k}\right)=\mathrm{V}\left[\left(\mathrm{M} \geq M_{1}\right),\left(\mathrm{M} \geq M_{2}\right), \ldots,\left(\mathrm{M} \geq M_{k}\right)\right]
$$




$$
=\min V\left(\mathrm{M} \geq M_{i}\right), \quad i=1,2, \ldots, k
$$

We assume that the weight vectors with respect to each criterion are:

$$
d^{\prime}\left(A_{i}\right)=\min V\left(S_{i} \geq S_{k}\right), \quad k=1,2, \ldots, n ; \quad k \neq i
$$

Then, the weight vector is given as follows:

$W^{\prime}=\left(d^{\prime}\left(A_{1}\right), d^{\prime}\left(A_{2}\right), \ldots, d^{\prime}\left(A_{n}\right)\right)^{T}, \quad i=1,2, \ldots, n$

Step 4: Finally, a normalisation procedure is applied. The normalised weight vector is given by:

$$
W=\left(d\left(A_{1}\right), d\left(A_{2}\right), \ldots, d\left(A_{n}\right),\right)^{T}, \quad i=1,2, \ldots, n
$$

where $W$ is a non-fuzzy number.

\section{Data Analysis}

There is limited academic focus on the barriers that affect sustainability implementation in UK cheese supply chains and, in particular, artisan producers. Therefore, this study contributes to this research gap in the implementation of sustainability practices in cheese supply chains. This is done by introducing fuzzy AHP to evaluate the internal and external barriers impacting sustainability implementation in this sector. The calculation steps of the fuzzy AHP (Chang 1996; Sirisawat and Kiatcharoenpol 2018) for the identification of the weights of sustainability barriers are given below.

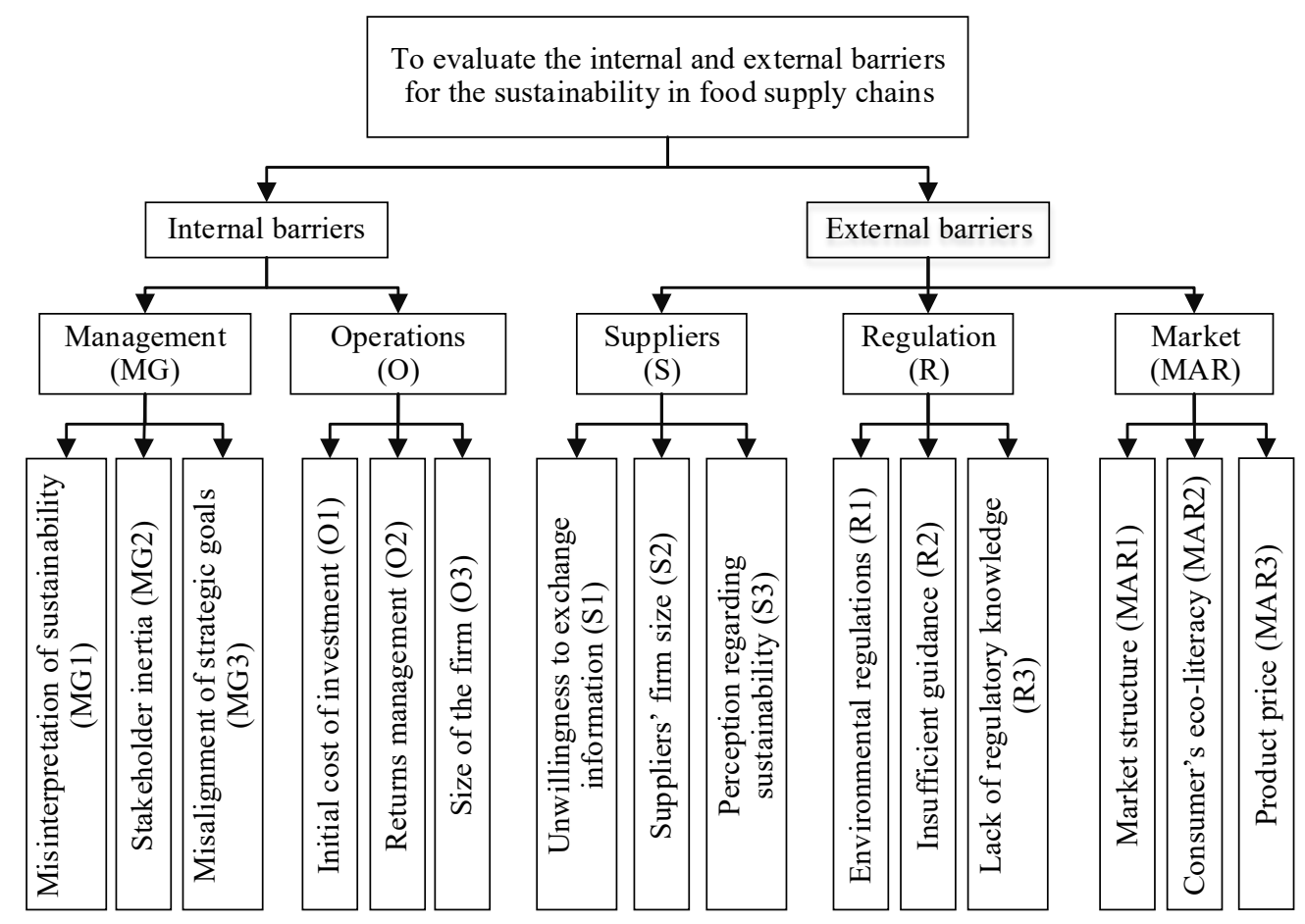

Figure 2. Hierarchical structure for the barriers of sustainability implementation 
Categories and sub-categories of sustainability barriers (see Figure 2) are compared by 255 UK artisan cheese producers with respect to their importance by using nine linguistic judgements. These relative importance values are converted to triangular fuzzy numbers (TFNs) to incorporate the uncertainty in the evaluations of decision makers. The nine linguistic variables and corresponding triangular fuzzy numbers are given in Appendix I. As an example, if a respondent states that management category is strongly more important than the regulation category, then it takes the fuzzy triangular value of $(6,7,8)$. In that case, the pairwise comparison value of the regulation category to the management category will be $(1 / 8,1 / 7,1 / 6)$.

Table 3. Fuzzy pairwise comparison matrix of five sustainability barrier categories

\begin{tabular}{cccccc}
\hline & MG & O & S & R & MA \\
\hline MG & $(1.00,1.00,1.00)$ & $(0.31,0.46,0.88)$ & $(1.00,1.93,2.85)$ & $(0.88,0.91,1.00)$ & $(0.88,0.91,0.99)$ \\
$\mathbf{O}$ & $(1.24,2.24,3.24)$ & $(1.00,1.00,1.00)$ & $(2.55,3.55,4.55)$ & $(1.11,2.04,2.96)$ & $(0.99,1.90,2.82)$ \\
S & $(0.38,0.54,1.00)$ & $(0.22,0.29,0.41)$ & $(1.00,1.00,1.00)$ & $(0.32,0.47,0.93)$ & $(0.25,0.34,0.53)$ \\
R & $(1.00,1.18,1.36)$ & $(0.37,0.52,0.96)$ & $(1.22,2.22,3.22)$ & $(1.00,1.00,1.00)$ & $(0.95,0.96,0.99)$ \\
MA & $(1.02,1.20,1.38)$ & $(0.39,0.56,1.04)$ & $(1.96,2.96,3.96)$ & $(1.02,1.09,1.16)$ & $(1.00,1.00,1.00)$ \\
\hline
\end{tabular}

There are 255 respondents; therefore, the fuzzy triangular number for the preference of $\mathrm{i}^{\text {th }}$ category over $\mathrm{j}^{\text {th }}$ category $\left(\tilde{a}_{i j}\right)$ is calculated by taking the average of the preferences of 255 decision makers. Table 3 represents the fuzzy pairwise comparison matrix of the respondents for the sustainability barrier categories in fuzzy scale. Table 4-8 shows the average fuzzy triangular fuzzy values for pairwise comparisons of the sub-categories of management, operations, suppliers, regulation, and market barriers, respectively.

Table 4. Fuzzy pairwise comparison matrix of sub-categories of management barrier

\begin{tabular}{lccc}
\hline & MG1 & MG2 & MG3 \\
\hline MG1 & $(1.00,1.00,1.00)$ & $(1.07,1.53,1.98)$ & $(0.59,0.69,1.00)$ \\
MG2 & $(0.69,0.76,0.97)$ & $(1.00,1.00,1.00)$ & $(0.32,0.47,0.92)$ \\
MG3 & $(1.00,1.62,2.24)$ & $(1.22,2.22,3.22)$ & $(1.00,1.00,1.00)$ \\
\hline
\end{tabular}


Table 5. Fuzzy pairwise comparison matrix of sub-categories of operations barrier

\begin{tabular}{cccc}
\hline & O1 & O2 & O3 \\
\hline O1 & $(1.00,1.00,1.00)$ & $(1.00,1.75,2.49)$ & $(1.56,2.56,3.56)$ \\
O2 & $(0.50,0.63,1.00)$ & $(1.00,1.00,1.00)$ & $(1.02,1.31,1.60)$ \\
O3 & $(0.37,0.50,0.88)$ & $(0.80,0.85,0.99)$ & $(1.00,1.00,1.00)$ \\
\hline
\end{tabular}

Table 6. Fuzzy pairwise comparison matrix of sub-categories of supplier's barrier

\begin{tabular}{cccc}
\hline & S1 & S2 & S3 \\
\hline S1 & $(1.00,1.00,1.00)$ & $(0.66,0.74,0.97)$ & $(0.71,0.78,1.00)$ \\
S2 & $(1.05,1.56,2.07)$ & $(1.00,1.00,1.00)$ & $(1.00,1.13,1.25)$ \\
S3 & $(1.00,1.44,1.87)$ & $(0.92,0.94,1.00)$ & $(1.00,1.00,1.00)$ \\
\hline
\end{tabular}

Table 7. Fuzzy pairwise comparison matrix of sub-categories of regulation barrier

\begin{tabular}{cccc}
\hline & R1 & R2 & R3 \\
\hline R1 & $(1.00,1.00,1.00)$ & $(0.62,0.72,1.00)$ & $(0.96,1.41,1.87)$ \\
R2 & $(1.00,1.51,2.02)$ & $(1.00,1.00,1.00)$ & $(1.00,1.95,2.89)$ \\
R3 & $(0.67,0.75,1.00)$ & $(0.33,0.50,1.00)$ & $(1.00,1.00,1.00)$ \\
\hline
\end{tabular}

Table 8. Fuzzy pairwise comparison matrix of sub-categories of market barrier

\begin{tabular}{lccc}
\hline & MA1 & MA2 & MA3 \\
\hline MA1 & $(1.00,1.00,1.00)$ & $(0.99,1.68,2.38)$ & $(0.81,0.85,1.00)$ \\
MA2 & $(0.54,0.67,1.04)$ & $(1.00,1.00,1.00)$ & $(0.35,0.53,1.04)$ \\
MA3 & $(1.00,1.29,1.58)$ & $(0.99,1.97,2.96)$ & $(1.00,1.00,1.00)$ \\
\hline
\end{tabular}

The value of fuzzy synthetic extent with respect to each barrier is calculated by using equation 2 . Then, the degree of possibility of the categories and sub-categories are calculated by using equation 3 and 4 . The weight vectors with respect to each category are calculated by taking the minimum value of degree of possibility for each category. The degree of possibility of the main categories for sustainability barriers are given in the following:

$$
\begin{gathered}
d^{\prime}(M G)=\min V\left(S_{1}=S_{k}\right)=\min (0.4145,1.0000,0.8930,0.7570)=0.4145 \\
d^{\prime}(O)=\min V\left(S_{2}=S_{k}\right)=\min (1.0000,1.0000,1.0000,1.0000)=1.0000 \\
d^{\prime}(S)=\min V\left(S_{3}=S_{k}\right)=\min (0.4581,0.0044,0.3578,0.2175)=0.0044 \\
d^{\prime}(R)=\min V\left(S_{4}=S_{k}\right)=\min (1.0000,0.5085,1.0000,0.8676)=0.5085 \\
d^{\prime}(M A R)=\min V\left(S_{5}=S_{k}\right)=\min (1.0000,0.6202,1.0000,1.0000)=0.6202
\end{gathered}
$$

The weight vectors for sustainability barriers are as follows:

$$
W^{\prime}=(0.4145,1.0000,0.0044,0.5085,0.6202)
$$

The final weight vector is found by the normalisation of this vector: 


$$
W=(0.163,0.393,0.002,0.200,0.243)
$$

The weights of the sub-criteria in each category are calculated similarly. Table 9 gives the local and global weights of the categories and sub-categories of sustainability barrier. The overall ranking is established based on the global weights. Global weights are calculated by multiplying the local weight of each specific barrier with its corresponding local weight of the barrier category (Saaty and Vargas 2012).

It is evident from Table 9 that the sub-barriers related to the operations barrier are the priority. This is believed to be due to their association with the cost, a factor which has been identified in the literature as the most significant inhibitor of the sustainable development (Tseng et al. 2013). The next highest weight is affiliated with the market category. The poor market structure of the artisan cheese producers is an evident barrier to sustainability. The regulation barrier category ranked third, with management and supplier barrier categories ranking fourth and fifth respectively. Misinterpretation of sustainability was acknowledged by more than half the respondents, making a significant impact on sustainable strategy implementation. The low weights of Management sub-barriers reveal the unique nature of owner-management orientation and traditional outlook of the artisan cheese producers. Supplier barrier category obtained a significant low value compared to the other identified barrier. This is an interesting finding which can be justified by the number of cheese producers sourcing the milk externally $(45 \%+)$.

Although SMEs suffer from financial constraints, they reap the benefits of organisational flexibility (Love and Roper 2015). It is clear that the artisan cheese producers are aware of their inability to focus on mid to long-term objectives (MG3). Furthermore, the low priority assigned to the stakeholder inertia (MG2) and misinterpretation of sustainability (MG1) in the Management barrier reveals that the MEs' principal constraint towards sustainability is not related to their unwillingness but, rather, to the investment cost (O1). Nevertheless, the low rank of the misinterpretation of sustainability (MG1) sub-barrier should not be underestimated, as it is associated with the lack of consensus surrounding the concept of sustainability within different cheese producers. This was evident mainly through in-person survey data, where several respondents asked the meaning of sustainability, before filling the questionnaire on several occasions. Further, the MG1 sub-barrier in section 1 of the questionnaire was left blank by numerous respondents, indicating a lack of clarity on the topic of sustainability. 
Table 9. Final ranking of the sustainability barriers and their sub-categories

\begin{tabular}{llllll}
\hline $\begin{array}{l}\text { Barrier } \\
\text { Category }\end{array}$ & $\begin{array}{l}\text { Local } \\
\text { Weight }\end{array}$ & $\begin{array}{l}\text { Specific } \\
\text { Barriers }\end{array}$ & $\begin{array}{l}\text { Local } \\
\text { Weight }\end{array}$ & $\begin{array}{l}\text { Global } \\
\text { Weight }\end{array}$ & $\begin{array}{l}\text { Global } \\
\text { Rank }\end{array}$ \\
\hline Management & 0.163 & MG 1 & 0.312 & 0.051 & 9 \\
& & MG 2 & 0.17 & 0.028 & 12 \\
MG 3 & 0.518 & 0.084 & 6 \\
& & & & & \\
Suppliers & 0.393 & O 1 & 0.593 & 0.233 & 1 \\
& & O 2 & 0.261 & 0.103 & 3 \\
& & O 3 & 0.146 & 0.057 & 8 \\
Regulation & 0.002 & S 1 & 0.175 & 0.0004 & 15 \\
& & S 2 & 0.451 & 0.0009 & 13 \\
& & S 3 & 0.375 & 0.0008 & 14 \\
& 0.200 & R 1 & 0.316 & 0.063 & 7 \\
& & R 2 & 0.483 & 0.097 & 4 \\
Market & & R 3 & 0.201 & 0.040 & 11 \\
& & & & & \\
& 0.243 & MA 1 & 0.355 & 0.086 & 5 \\
& & MA 2 & 0.198 & 0.048 & 10 \\
& & MA 3 & 0.447 & 0.109 & 2 \\
\hline
\end{tabular}

Regarding the operations barrier category, the level of initial investment (O1) is found to be vital for the implementation of sustainable practices. This factor was found to influence the dairy SMEs' lack of progress in the development of green practices. Its ranking reveals that artisan cheese producers are unable to confront additional sustainability implementation costs. Some respondents claimed that unless a financial aid is created, they cannot engage in any green initiatives. Returns management $(\mathrm{O} 2)$ with a good reverse logistics network is the second priority identified by UK artisan cheese producers. Typically, artisan cheese producers recognise the importance of the reverse logistics system with growing product recalls related to the contamination as evidenced by the survey results for the returns management $(\mathrm{O} 2)$ barrier. However, due to the investment cost (O1) barrier, they are not eager to invest in reverse logistics practices. The respondents shared their rising concerns over cheese micro-biological contamination through foodborne pathogens. Sustainability, perceived as a solution to contain contamination and fraud risks, if not introduced, poses a greater threat to a firm's survival.

Supplier's lack of information sharing (S1) is highlighted as one of the least important factors for sustainability, attributed only to the fear of exhibiting poor performance. The 
analysis placed it at the end, behind suppliers' perception regarding sustainability (S3). Interestingly, supplier firm size (S2) was ranked relatively higher in the priority over other Supplier sub-barriers. Owing to the highly perishable nature of the milk as well as high-quality standards expected of the artisan cheese, most dairy producers source milk directly from their local farms. Other ingredients may be sourced from secondary suppliers depending on different characteristics and needs of each speciality cheese. The short upstream length of the supply chain (Figure 1) provides a high level of transparency, which justifies the lowest ranking for unwillingness to share the information (S1). In the dairy industry, first-tier suppliers are substantially engaged in the sustainability process, as they play a major role in price negotiation (Schulze-Ehlers et al. 2014; Wilhelm et al. 2016). However, the extent of their involvement is linked to their resource capabilities, which are limited on account of their firm size and market price pressures. Supplier barrier, having the lowest priority ranking, supports this theory.

In the regulation barrier category, inadequate authorities support (R2) ranks first within the category and overall fourth after initial investment cost (O1), product price (MA3), and returns management $(\mathrm{O} 2)$. Environmental legislation $(\mathrm{R} 1)$ ranks seventh showing that although it urges cheese producers to adopt sustainable strategies, it does not take into account SMEs' unique characteristics. Lack of knowledge regarding regulations (R3) is not found to be a major concern for artisan cheese producers as they are aware of changing government regulations. A majority of the respondents confirmed knowledge-sharing related to UK government regulations in the dairy supply chain. Nevertheless, UK artisan cheese producers operate under a regulatory framework, which despite urging them towards sustainability, does not provide supporting funds for the implementation.

In the market barrier category, product price (MA3) is the dominant sub-barrier ranking second. Artisanal cheese is a speciality product; thus, its market price is significantly higher than conventional dairy products. As a consequence, the integration of sustainable processes will further increase production costs. This cost of investment will be transferred to the market price for the product to maintain the same profit margin. It is apparent that this would be problematic for the firm, as consumers may not be willing to bear this additional cost of sustainability. Moreover, their strong local market focus limits their ability to attract investment, setting a high fixed cost for any innovative initiatives. Hence, cheese producers struggle to implement sustainable practices due to their high dependency on their customers and insufficient stable profit level. Lower ranking of a customer's eco-literacy (MA2) demonstrates that cheese producers do not consider it to be a burden to sustainability 
integration, as it is driven by customers in the supply chain network. This is mainly due to the traditional craftsmanship of artisanal cheese, which is perceived by most consumers as a synonym of an environmentally friendly production method of a premium quality. This environmental awareness of consumers is a strong driver for sustainability in the artisan cheese supply chain network.

\section{Sensitivity Analysis}

The objective of the sensitivity analysis is to examine the impact of one barrier over another. We analyse the impact of highest priority on the other categories and subsequently on the ranking of the individual barriers. As the calculation of global weights is based on the weighted sum model, the global priorities of each barrier are dependent on the weight of their corresponding category (Triantaphyllou and Sánchez 1997). Changes in the local weights of each category could affect the final ranking of these individual barriers (Govindan et al. 2014). As seen in Table 9, the operations barrier is the priority. To assess its impact on the other barriers, the research employs the numerical incremental analysis method. Incremental analysis is a decision-making tool to understand the effect of a change in the value of an alternative to other alternatives (Chen and Kocaoglu 2008). The local weight of the operations barrier (alternative) is varied between \pm 0.03-0.3 creating ten different scenarios for the simulation study. The impact of these variations on the other categories is shown in Table 10. The column with bold values represents the initial weights before conducting the sensitivity analysis. The variations in the sub-categories due to the changes in the weight of the operations barrier are also illustrated in Figure 3. The top five sub-barriers that are affected from the changes in the operations category, mostly, are MG3, R2, MG1, R1, and MG2, respectively (supplier barrier is excluded from this ordering because the degree of possibility values for this category were 0 of to a level). Therefore, especially, the management and regulation barriers can be regarded as the most influential barriers to sustainability implementation.

Table 10. Barrier category values in sensitivity analysis

\begin{tabular}{cccccccccccccc}
\hline $\begin{array}{c}\text { Barrier } \\
\text { Category }\end{array}$ & \multicolumn{1}{c}{ weight of operations category decreases $\leftarrow \begin{array}{c}\text { Current } \\
\text { values }\end{array}$} & \multicolumn{5}{c}{$\rightarrow$ weight of operations category } \\
increases
\end{tabular}


Ghadge, A. Er-Kara, M., Mogale, D.G., Choudhary, S. and Dani, S. (2020), Sustainability implementation challenges in

food supply chains: A case of UK artisan cheese producers, Production Planning and Control, accepted.

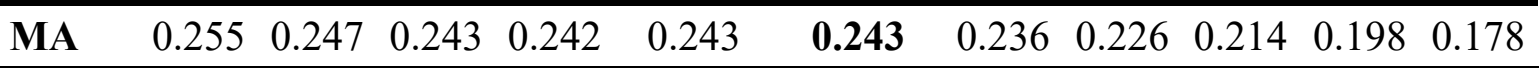

Concerning the whole spectrum of weight values from \pm 0.03-0.3 (Figure 3 ) the initial investment cost $(\mathrm{O} 1)$ exhibits the highest change with a decrease in the weight of the Operations barrier. The result validates the initial cost of investment as the most important factor for successful sustainability implementation. Return on investment (O2) also displays a high variation, but the transition between ranks is smoother with a decrease in weights as seen in Figure 3. Supplier's unwillingness to exchange information (S1) and consumer's ecoliteracy (MAR2), are the least influenced barriers in terms of their priority. None of the barriers from the market barrier category (MAR1, MAR2, MAR3) deviate significantly from their initial position.

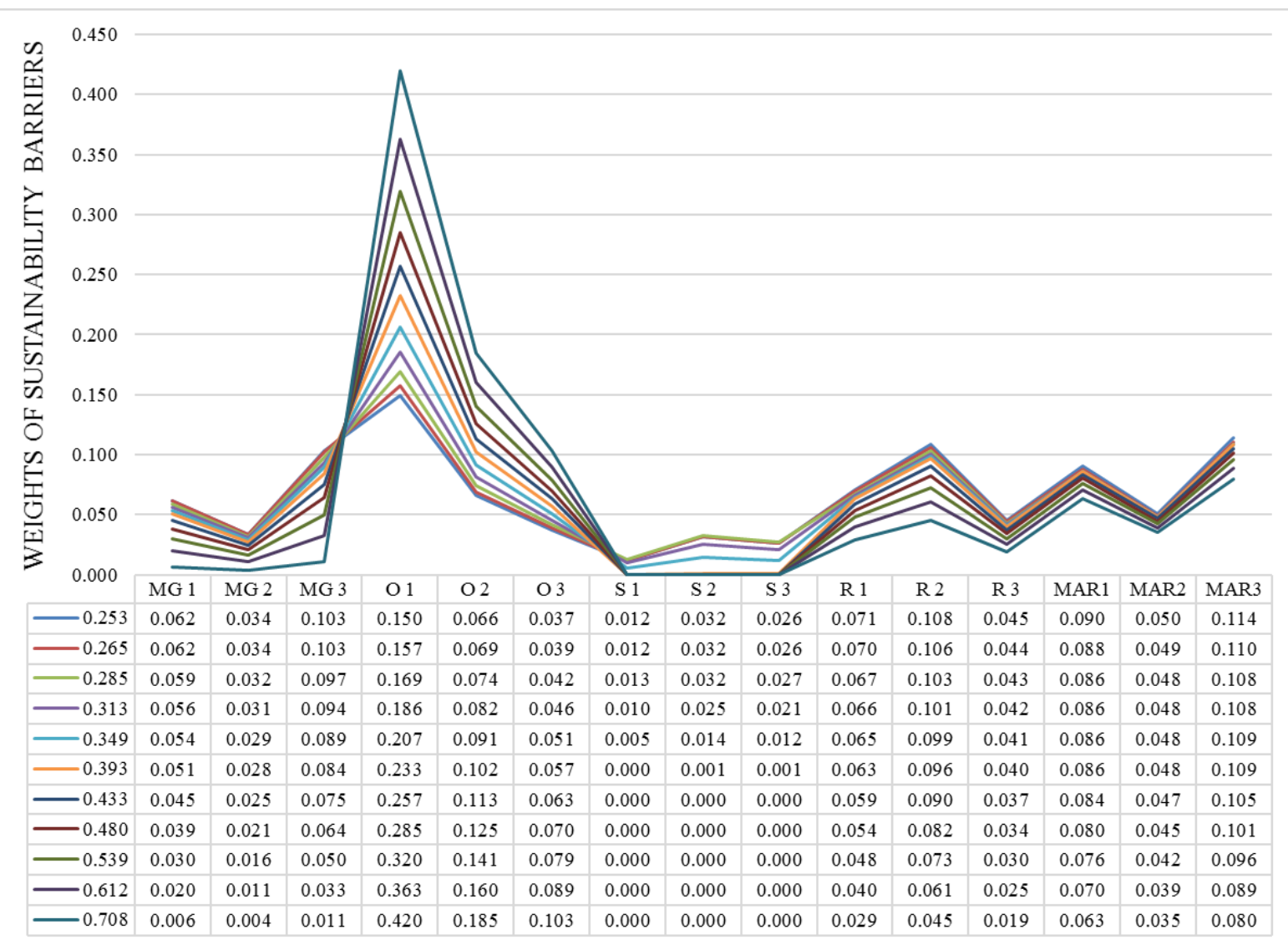

Figure 3. Variations in the weights due to changes in the weight of the operations barrier

When the weight of the operations barrier decreases to 0.253 , the marketing barrier rises to the first priority and, among the subcategories, product price (MAR3) rises to the second order after initial investment cost (O1). Short-term focus on the strategic goals (MG3) 
is related to the SMEs' organisational inability to focus on mid- and long-term objectives (Ates and Bititci 2011). Therefore, assuming that the financial needs (O1) have been successfully covered, the extent to which artisan cheese producers are going to implement sustainable practices depends on their eagerness to overcome their short-term focus orientation (MG3). Sensitivity analysis confirms the insignificant impact of the supplier barrier on sustainability implementation in the UK artisan cheese industry. The results also show that, as the internal factors (Management and Operations) are resolved, the importance of government regulations will play a vital role in driving sustainability in the UK food supply chain.

\section{Conclusion}

\subsection{Discussion}

This research has focused on artisan cheese producers in the UK to provide useful insights into the challenges faced by dairy supply chains. The factors identified through the literature review are classified into internal and external barriers. For each category of barrier, three important sub-barriers were identified. The barriers were ranked using the fuzzy AHP approach. The analysis indicated that the operations barrier category was the most significant to the sustainable development of the focal firm. An initial cost of investment due to small firm size is found to be the major barrier for artisan cheese producers across the UK under the operations category. The market product cost is also identified to be one of the critical factors for sustainability, as the cost of artisan cheese is relatively higher than regular cheese. Sustainability-driven practices are expected to increase product cost. A numerical incremental study conducted through sensitivity analysis reflected the impact of the barriers over one another. The dairy sector is subjected to constant introduction of new environmental legislation/regulation from both European and international authorities. Internal factors such as management and external factors such as governmental regulation also significantly influence sustainability implementation. This research has holistically studied different factors to identify and prioritise the barriers for sustainability implementation across the food supply chains and, in particular, the UK artisan cheese supply chain network.

\subsection{Research and managerial implications}

The findings of this research propose that the prioritised factors will help artisan cheese producers in better understanding the complexities involved in implementing sustainability 
within their business. The developed insights may not be significantly new and add to similar past studies conducted in the Indian manufacturing (e.g., Mathiyazhagan et al. 2013; Mor et al. 2018; Mitra and Datta 2014) and Greek food sector (e.g., Bourlakis et al. 2014a; Bourlakis 2014b, Ghadge et al. 2017). However, it is understood that sector-specific or country-specific supply chains differ (Kittipanya-Ngam and Tan, 2020; León-Bravo et al. 2020) and thus, sustainability implementation challenges faced by them differ based on specific characteristics and nature of structure. Nevertheless, it is interesting to observe lack of consensus regarding the concept of sustainability in developed country like UK. Thus, awareness of sustainability in general and the competitive advantage it brings is central to the implementation across various supply chains. Post COVID-19 supply chains will certainly have to be more resilient (Ivanov and Dolgui 2020), and practicing sustainability practices could help to better achieve it. Similar studies across different developed and developing countries will help to capture a comprehensive picture of sustainability issues in the global FSC. The findings are useful for Agri-food practitioners in understanding sustainability requirements for creating a sustainable competitive advantage. The understanding of different sustainability barriers and their influence on each other can help managers in better managing the sustainability implementation process and, specifically, in artisan and other SMEs. The research further guides in developing operational strategies for implementing sustainability in Food SMEs. The identified internal and external factors can support in building a framework for sustainability implementation in food supply chains. The study is believed to be first of its kind in the UK artisan food supply chain and can guide in developing new frameworks for the implementation of sustainability.

\subsection{Limitations and future research}

Although the overall response rate is acceptable for the study, the data lacked poor representation from Northern Ireland, a part of the UK. Several initiatives were taken to improve the representation of nations in the UK; however, the rate of response was relatively slow and unevenly distributed across the regions. Also, the study was restricted due to a limited number of survey responses, and a higher response rate would have brought robustness to the findings. Unfortunately, the number of UK dairy farmers have halved in the last decade due to falling milk prices (Guardian News 2015) and this is believed to be the reason for the reduction in the number of artisan cheese producers across the UK. The case studied the factors influencing the implementation of sustainable practices to the specific sector of UK artisan cheese producers. Hence, the study lacks the generalisation of the findings for the wider food 
or dairy supply chain. However, as the study focusses on the UK dairy sector, the research insights may help dairy product manufacturers in achieving some of the set targets by Dairy UK (refer to Dairy Roadmap 2015 for more information). The subjective views of the respondents can be considered as an intrinsic limitation of multiple-criteria decision models (Alexander et al. 2014).

It would be insightful to explore further the artisan cheese producers' perceptions about sustainability. Another future research direction could include a focused study on each barrier category to obtain an intrinsic view of each inhibitor's causal factors. Concerning the dairy supply chain in general, waste management, reduction in $\mathrm{CO}_{2}$ emissions and reverse logistics constitute major sustainability issues, which could be further investigated.

Acknowledgement: Authors would like to thank two reviewers and guest editor for their constructive recommendations for improving the quality of manuscript. Authors acknowledge the support of Mr Meletios Bimpizas-Pinis from Heriot Watt University, UK for preliminary data collection and modelling activity.

\section{References}

Abbasi, M., \& Nilsson, F. (2012). Themes and Challenges in Making Supply Chains Environmentally Sustainable. Supply Chain Management: An International Journal, 17(5), 517-530.

Ageron, B., Gunasekaran, A., \& Spalanzani, A. (2012). Sustainable Supply Management: An Empirical Study. International Journal of Production Economics, 140(1), 168-182.

Alexander, A., Walker, H., \& Naim, M. (2014). Decision Theory in Sustainable Supply Chain Management: A Literature Review. Supply Chain Management: An International Journal, 19(5/6), 504-522.

Ates, A., \& Bititci, U. (2011). Change Process: A Key Enabler for Building Resilient SMEs. International Journal of Production Research, 49(18), 5601-5618.

Ateş, M. A., Bloemhof, J., van Raaij, E. M., \& Wynstra, F. (2012). Proactive environmental strategy in a supply chain context: the mediating role of investments. International Journal of Production Research, 50(4), 1079-1095.

Beske, P., Land, A., \& Seuring, S. (2014). Sustainable supply chain management practices and dynamic capabilities in the food industry: A critical analysis of the literature. International Journal of Production Economics, Vol. 152, 131-143.

Blome, C., Schoenherr, T., \& Eckstein, D. (2014). The impact of knowledge transfer and complexity on supply chain flexibility: A knowledge-based view. International Journal of Production Economics, Vol. 147, 307-316.

Bouma, A., Durham, C.A., \& Meunier-Goddik, L. (2014). Start-up and operating costs for artisan cheese companies. Journal of dairy science, 97(6), 3964-3972. 
Bourlakis, M., Maglaras, G., Aktas, E., Gallear, D., \& Fotopoulos, C. (2014a). Firm Size and Sustainable Performance in Food Supply Chains: Insights from Greek SMEs. International Journal of Production Economics, Vol. 152, 112-130.

Bourlakis, M., Maglaras, G., Gallear, D., \& Fotopoulos, C. (2014b). Examining Sustainability Performance in the Supply Chain: The Case of the Greek Dairy Sector. Industrial Marketing Management, 43(1), 56-66.

Carter, C.R., \& Rogers, D.S. (2008). A Framework of Sustainable Supply Chain Management: Moving Toward New Theory. International Journal of Physical Distribution and Logistics Management, 38(5), 360-387.

Chang, D.Y. (1996). Applications of the extent analysis method on fuzzy AHP. European Journal of Operational Research, 95, 649-655.

Chkanikova, O., \& Mont, O. (2015). Corporate supply chain responsibility: drivers and barriers for sustainable food retailing. Corporate Social Responsibility and Environmental Management, 22(2), 65-82.

Choudhary, S., Nayak, R., Dora, M., Mishra, N., \& Ghadge, A. (2019). An integrated lean and green approach for improving sustainability performance: a case study of a packaging manufacturing SME in the UK. Production Planning \& Control, 30(5-6), 353-368.

Ciliberti, F., Pontrandolfo, P., \& Scozzi, B. (2008). Investigating corporate social responsibility in supply chains: a SME perspective. Journal of Cleaner Production, 16(15), 15791588.

Chen, H., \& Kocaoglu, D. F. (2008). Decision Support: A Sensitivity Analysis Algorithm for Hierarchical Decision Models. European Journal of Operational Research, 185(1), 266-288.

Cole, R., \& Aitken, J. (2019). Selecting suppliers for socially sustainable supply chain management: post-exchange supplier development activities as pre-selection requirements. Production Planning \& Control, 30(14), 1184-1202.

Dairy Roadmap (2015). Environmental Sustainability Report. http://www.dairyuk.org/images/documents/publications/2015 Dairy Roadmap.pdf. Accessed 30 ${ }^{\text {th }}$ April, 2020.

Darnall, N., Henriques, I., \& Sadorsky, P. (2010). Adopting proactive environmental strategy: The influence of stakeholders and firm size. Journal of management studies, 47(6), 1072-1094.

Diabat, A., \& Govindan, K. (2011). An analysis of the drivers affecting the implementation of green supply chain management. Resources, Conservation and Recycling, 55(6), 659667.

Durham, C.A., Bouma A., \&Meunier-Goddik, L. (2015). A decision-making tool to determine economic feasibility and break-even prices for artisan cheese operations. Journal of Dairy Science, 98, 8319-8332.

Elkington, J. (1998). Partnerships from cannibals with forks: The triple bottom line of 21stcentury business. Environmental Quality Management, 8(1), 37-51.

European Commission (2015). User Guide to the SME Definition. http://ec.europa.eu/growth/toolsdatabases/newsroom/cf/itemdetail.cfm?item id=8274\&lang=en. Accessed $30^{\text {th }}$ April, 2020.

Fonterra (2014). http://www2.fonterra.com/our-financials/the-global-dairy-industry Accessed $30^{\text {th }}$ April, 2020.

Gadenne, D.L., Kennedy, J., \& McKeiver, C. (2009). An empirical study of environmental awareness and practices in SMEs. Journal of Business Ethics, 84(1), 45-63. 
Ghadge, A., Kaklamanou, M., Choudhary, S., \& Bourlakis, B. (2017). Implementing environmental practices within the Greek dairy supply chain: Drivers and barriers for SMEs. Industrial Management \& Data Systems, 117(9), 1995-2014.

Ghadge, A., Wurtmann, H., \& Seuring, S. (2019). Managing climate change risks in global supply chains: a review and research agenda. International Journal of Production Research, 1-21.

Giunipero, L.C., Hooker, R.E., \& Denslow, D. (2012). Purchasing and Supply Management Sustainability: Drivers and Barriers. Journal of Purchasing and Supply Management, 18(4), 258-269.

Glover, J.L., Champion, D., Daniels, K.J., \& Dainty, A.J.D. (2014). An Institutional Theory Perspective on Sustainable Practices across the Dairy Supply Chain. International Journal of Production Economics, Vol. 152, 102-111.

Govindan, K., Kaliyan, M., Kannan, D., \& Haq, A.N. (2014). Barriers Analysis for Green Supply Chain Management Implementation in Indian Industries Using Analytic Hierarchy Process. International Journal of Production Economics, Vol. 147 No. B, 555-568.

Grekova, K., Calantone, R.J., Bremmers, H.J., Trienekens, J.H., \& Omta, S.W.F. (2016). How environmental collaboration with suppliers and customers influences firm performance: Evidence from Dutch food and beverage processors. Journal of Cleaner Production, Vol. $112,1861-1871$.

Grimm, J.H., Hofstetter, J.S., \& Sarkis, J. (2014). Critical Factors for Sub-Supplier Management: A Sustainable Food Supply Chains Perspective. International Journal of Production Economics, Vol. 152, 159-173.

Gualandris, J., \& Kalchschmidt, M. (2014). Customer Pressure and Innovativeness: Their Role in Sustainable Supply Chain Management. Journal of Purchasing and Supply Management, 20(2), 92-103.

Guardian news (2015). https://www.theguardian.com/science/2015/jan/12/dairy-industrycrisis-falling-milk-prices-national-farmers-union. Accessed 30 $0^{\text {th }}$ April, 2020.

Guo, C. (2007). Is Sustainable Competitive Advantage an Achievable Holy Grail: The Relevance Gap between Academia and Business. Journal of Business \& Management, 13(2).

Hamprecht, J., Corsten, D., Noll, M., \& Meier, E. (2005). Controlling the sustainability of food supply chains. Supply Chain Management: An International Journal, 10(1), 7-10.

Holmann, F.J. (2001). Milk market of small scale artisan cheese factories in selected livestock watersheds of Honduras and Nicaragua. Livestock Research for Rural Development, 13(1).

Ivanov, D., \& Dolgui, A. (2020). A digital supply chain twin for managing the disruption risks and resilience in the era of Industry 4.0. Production Planning \& Control, 1-14.

Javanbarg, M.B., Scawthorn, C., Kiyono, J., \& Shahbodaghkhan, B. (2012). Fuzzy AHP-based multicriteria decision making systems using particle swarm optimization. Expert Systems with Applications, 39(1), 960-966.

Johnson, D. and Turner, C. (2000), European Business, Routledge, London.

Kanji, G.K., \& Chopra, P.K. (2010). Corporate social responsibility in a global economy. Total Quality Management, 21(2), 119-143.

Kittipanya-Ngam, P., \& Tan, K. H. (2020). A framework for food supply chain digitalization: lessons from Thailand. Production Planning \& Control, 31(2-3), 158-172.

Kuo, J.C., \& Chen, M.C. (2010). Developing an advanced multi-temperature joint distribution system for the food cold chain. Food control, 21(4), 559-566. 
Le, S., Bazger, W., Hill, A.R., \& Wilcock, A. (2014). Awareness and perceptions of food safety of artisan cheese makers in Southwestern Ontario: A qualitative study. Food Control, Vol. 41, 158-167.

León-Bravo, V., Caniato, F., \& Caridi, M. (2020). Sustainability assessment in the food supply chain: study of a certified product in Italy. Production Planning \& Control, 1-18.

Longoni, A., \& Cagliano, R. (2015). Environmental and Social Sustainability Priorities: Their Integration in Operations Strategies. International Journal of Operations and Production Management, 35(2), 216-245.

Love, J. H., \& Roper, S. (2015). SME innovation, exporting and growth: A review of existing evidence. International Small Business Journal, 33(1), 28-48.

NY Times (2010).

http://www.nytimes.com/2010/11/20/business/20artisanside.html?mcubz=0. Accessed $30^{\text {th }}$ April, 2020.

Malhotra, M.K., \& Grover, V. (1998). An Assessment of Survey Research in POM: From Constructs to Theory. Journal of Operations Management, 16(4), 407-425.

Mogale, D. G., Cheikhrouhou, N., \& Tiwari, M. K. (2019a). Modelling of sustainable food grain supply chain distribution system: a bi-objective approach. International Journal of Production Research, 1-24.

Mogale, D. G., Ghadge, A., Kumar, S. K., \& Tiwari, M. K. (2019b). Modelling supply chain network for procurement of food grains in India. International Journal of Production Research, 1-20.

Mollenkopf, D.A., Frankel, R., \& Russo, I. (2011). Creating Value through Returns Management: Exploring the Marketing-Operations Interface. Journal of Operations Management, 29(5), 391-403.

Mathiyazhagan, K., Govindan, K., NoorulHaq, A., \& Geng, Y. (2013). An ISM Approach for the Barrier Analysis in Implementing Green Supply Chain Management. Journal of Cleaner Production, Vol. 47, 283-297.

Mitra, S., \& Datta, P. P. (2014). Adoption of green supply chain management practices and their impact on performance: an exploratory study of Indian manufacturing firms. International Journal of Production Research, 52(7), 2085-2107.

Mudgal, R.K., Shankar, R., Talib, P., \& Raj, T. (2010). Modelling the barriers of green supply chain practices: an Indian perspective. International Journal of Logistics Systems and Management, 7(1), 81-107.

Ortas, E., Moneva, J.M., \& Álvarez, I. (2014). Sustainable Supply Chain and Company Performance. Supply Chain Management: An International Journal, 19(3), 332-350.

Qrunfleh, S., \& Tarafdar, M. (2014). Supply chain information systems strategy: Impacts on supply chain performance and firm performance. International Journal of Production Economics, Vol. 147, 340-350.

Ramirez, E., Gonzalez, R.J., \& Moreira, G.J. (2014). Barriers and Bridges to the Adoption of Environmentally-Sustainable Offerings. Industrial Marketing Management, 43(1), 1624.

Reuter, C., Goebel, P., \& Foerstl, K. (2012). The Impact of Stakeholder Orientation on Sustainability and Cost Prevalence in Supplier Selection Decisions. Journal of Purchasing and Supply Management, 18(4), 270-281.

Roehrich, J.K., Grosvold, J., \& Hoejmose, S.U. (2014). Reputational Risks and Sustainable Supply Chain Management: Decision Making Under Bounded Rationality. International Journal of Operations and Production Management, 34(5), 695-719.

Saaty, T.L., \& Vargas, L.G. (2012). Models, Methods, Concepts and Applications of the Analytic Hierarchy Process. $2^{\text {nd }}$ ed., New York: Springer. 
Sajjad, A., Eweje, G., \& Tappin, D. (2015). Sustainable supply chain management: motivators and barriers. Business Strategy and the Environment, 24(7), 643-655.

Sarkis, J., Zhu, Q. and Lai, K.H. (2011). An organizational theoretic review of green supply chain management literature. International Journal of Production Economics, 130(1), $1-15$.

Schäufele, I., \& Hamm, U. (2017). Consumers' perceptions, preferences and willingness-topay for wine with sustainability characteristics: A review. Journal of Cleaner production, 147, 379-394.

Schrettle, S., Hinz, A., Scherrer-Rathje, M., \& Friedli, T. (2014). Turning Sustainability into Action: Explaining Firms' Sustainability Efforts and Their Impact on Firm Performance. International Journal of Production Economics, Vol. 147 No. A, 73-84.

Schulze-Ehlers, B., Steffen, N., Busch, G., \& Spiller, A. (2014). Supply Chain Orientation in SMEs as an Attitudinal Construct Conceptual Considerations and Empirical Application to the Dairy Sector. Supply Chain Management: An International Journal, 19(4), 395-412.

Shaharudin, M.R., Zailani, S., \& Tan, K.C. (2015). Barriers to product returns and recovery management in a developing country: investigation using multiple methods. Journal of Cleaner Production, Vol. 96, 220-232.

Shibin, K. T., Dubey, R., Gunasekaran, A., Luo, Z., Papadopoulos, T., \& Roubaud, D. (2018). Frugal innovation for supply chain sustainability in SMEs: multi-method research design. Production Planning \& Control, 29(11), 908-927.

Silvestre, B. S. (2015). Sustainable Supply Chain Management in Emerging Economies: Environmental Turbulence, Institutional Voids and Sustainability Trajectories. International Journal of Production Economics, Vol. 167, 156-169.

Singh, R.K., Gunasekaran, A., \& Kumar, P. (2017). Third party logistics (3PL) selection for cold chain management: a fuzzy AHP and fuzzy TOPSIS approach. Annals of Operations Research, 1-23.

Sirisawat, P., \& Kiatcharoenpol, T. (2018). Fuzzy AHP-TOPSIS approaches to prioritizing solutions for reverse logistics barriers. Computers \& Industrial Engineering, Vol. 117, 303-318.

Soysal, M., Bloemhof-Ruwaard, J.M., \& van der Vorst, J.G.A.J. (2014). Modelling Food Logistics Networks with Emission Considerations: The Case of an International Beef Supply Chain. International Journal of Production Economics, Vol. 152, 57-70.

Stål, H.I. (2015). Inertia and change related to sustainability-An institutional approach. Journal of Cleaner Production, Vol. 99, 354-365.

Sustainable food trust (2017). http://sustainablefoodtrust.org/articles/artisan-cheese-fightsback-2/ Accessed 25 August 2017.

Svensson, G., \& Wagner, B. (2012). Implementation of a sustainable business cycle: the case of a Swedish dairy producer. Supply Chain Management: An International Journal, 17(1), 93-97.

Tian, Y., Govindan, K., \& Zhu, Q. (2014). A system dynamics model based on evolutionary game theory for green supply chain management diffusion among Chinese manufacturers. Journal of Cleaner Production, Vol. 80, 96-105.

Ting, S.L., Tse, Y.K., Ho, G.T.S., Chung, S.H., \& Pang, G. (2014). Mining Logistics Data to Assure the Quality in a Sustainable Food Supply Chain: A Case in the Red Wine Industry. International Journal of Production Economics, Vol. 152, 200-209.

Tseng, M. L., Tan, R. R., \& Siriban-Manalang, A. B. (2013). Sustainable consumption and production for Asia: sustainability through green design and practice. Journal of Cleaner Production, Vol. 40, 1-5. 
Triantaphyllou, E., \& Sánchez, A. (1997). A Sensitivity Analysis Approach for Some Deterministic Multi-Criteria Decision-Making Methods. Decision Sciences, 28(1), 151-194.

Uhlaner, L. M., Berent-Braun, M. M., Jeurissen, R. J., \& de Wit, G. (2012). Beyond size: Predicting engagement in environmental management practices of Dutch SMEs. Journal of Business Ethics, 109(4), 411-429.

Yakovleva, N. (2007). Measuring the Sustainability of the Food Supply Chain: A Case Study of the UK. Journal of Environmental Policy \& Planning, 9(1), 75-100.

Vachon, S., \& Klassen, R.D. (2008). Environmental management and manufacturing performance: The role of collaboration in the supply chain. International Journal of Production Economics, 111(2), 299-315.

Validi, S., Bhattacharya, A., \& Byrne, P. J. (2014). A Case Analysis of a Sustainable Food Supply Chain Distribution System-A Multi-Objective Approach. International Journal of Production Economics, Vol. 152, 71-87.

Van der Vaart, T., \& van Donk, D.P. (2008). A critical review of survey-based research in supply chain integration. International Journal of Production Economics, 111(1), 4255.

Varsei, M., Soosay, C., Fahimnia, B., \& Sarkis, J. (2014). Framing sustainability performance of supply chains with multidimensional indicators. Supply Chain Management: An International Journal, 19(3), 242-257.

Waldman, K.B., \& Kerr, J.M. (2015). Is Food and Drug Administration policy governing artisan cheese consistent with consumers' preferences? Food Policy, Vol. 55, 71-80.

Wang, Z., Mathiyazhagan, K., Xu, L., \& Diabat, A. (2016). A decision making trial and evaluation laboratory approach to analyze the barriers to Green Supply Chain Management adoption in a food packaging company. Journal of Cleaner Production, Vol. 117, 19-28.

Walker, H., Di Sisto, L., \& McBain, D. (2008). Drivers and Barriers to Environmental Supply Chain Management Practices: Lessons from the Public and Private Sectors. Journal of Purchasing and Supply Management, 14(1), 69-85.

Wilhelm, M.M., Blome, C., Bhakoo, V., \& Paulraj, A. (2016). Sustainability in Multi-tier Supply Chains: Understanding the Double Agency Role of the First-tier Supplier. Journal of Operations Management, Vol. 41, 42-60.

World Commission on Environment and Development (1987). Our Common Future. Oxford University Press, Oxford/New York.

Wu, Z., \& Pagell, M. (2011). Balancing Priorities: Decision-Making in Sustainable Supply Chain Management. Journal of Operations Management, 29(6), 577-590.

Xia, X., Govindan, K., \& Zhu, Q. (2015). Analyzing internal barriers for automotive parts remanufacturers in China using grey-DEMATEL approach. Journal of Cleaner Production, Vol. 87, 811-825.

Yusuf, Y.Y., Gunasekaran, A., Musa, A., Dauda, M., El-Berishy, N.M., \& Cang, S., (2014). A relational study of supply chain agility, competitiveness and business performance in the oil and gas industry. International Journal of Production Economics, 147, 531-543.

Zhu, Q., \& Sarkis, J. (2004). Relationships between operational practices and performance among early adopters of green supply chain management practices in Chinese manufacturing enterprises. Journal of Operations Management, 22(3), 265-289.

Zhu, Q., Sarkis, J., \& Lai, K. (2013). Institutional-based Antecedents and Performance Outcomes of Internal and External Green Supply Chain Management Practices. Journal of Purchasing and Supply Management, 19(2), 106-117. 
Ghadge, A. Er-Kara, M., Mogale, D.G., Choudhary, S. and Dani, S. (2020), Sustainability implementation challenges in food supply chains: A case of UK artisan cheese producers, Production Planning and Control, accepted.

\section{Appendix I: Membership function of linguistic scale}

\begin{tabular}{|l|l|l|}
\hline Fuzzy number & Linguistic & Scale of fuzzy number \\
\hline 9 & Perfect & $(8,9,10)$ \\
\hline 8 & Absolute & $(7,8,9)$ \\
\hline 7 & Very good & $(6,7,8)$ \\
\hline 6 & Fairly Good & $(5,6,7)$ \\
\hline 5 & Good & $(4,5,6)$ \\
\hline 4 & Preferable & $(3,4,5)$ \\
\hline 3 & Not bad & $(2,3,4)$ \\
\hline 2 & Weak Advantage & $(1,2,3)$ \\
\hline 1 & Equal & $(1,1,1)$ \\
\hline
\end{tabular}

